\title{
CHARACTERIZATION AND UTILIZATION OF REED STEM AS A LIGNOCELLULOSIC RESOURCE FOR PARTICLEBOARD PRODUCTION
}

\author{
Behzad Kord $^{1, \wedge}$, Mehdi Roohani $^{2}$, Behrouz Kord $^{3}$
}

\begin{abstract}
The objective of this study was to investigate the use of the reed stem in manufacturing three-layer particleboard. Variable factors were mixing ratio of reed and industrial wood particles $(0: 100,25: 75,50: 50$, $75: 25$ and 100:0 in the surface and middle layers), press temperature $\left(170,180,190{ }^{\circ} \mathrm{C}\right)$ and pressing cycle time (5, 6, $7 \mathrm{~min})$. Other parameters such as resin content ( $8 \%$ in core and $10 \%$ in faces), hardener content $(2 \%)$, press closing rate $(4,5 \mathrm{~mm} / \mathrm{min})$, press pressure $\left(30 \mathrm{~kg} / \mathrm{cm}^{2}\right)$, board thickness $(15 \mathrm{~mm})$, and target density $\left(700 \mathrm{~kg} / \mathrm{m}^{3}\right)$ were held constant. The physical and mechanical properties of particleboard panels including modulus of rupture, modulus of elasticity, internal bonding, water absorption and thickness swelling were determined according to the procedures of European standards. The results showed that modulus of rupture, modulus of elasticity, internal bond, water absorption and thickness swelling increased with the increase of reed particles content. The positive influence of press temperature and press time can also be seen in terms of improved physical and mechanical properties. Based on the findings of this study, we can conclude that reed stem can be used to manufacture particleboard.
\end{abstract}

Keywords: Mechanical properties, particleboards, physical properties, press temperature, pressing cycle time, reed.

\section{INTRODUCTION}

Particleboard is a wood-based panel product manufactured under pressure and temperature from particles of wood or other lignocellulosic fibrous materials and binder. It is used widely in the manufacture of furniture, floor underlayment, and interior decoration (wall and ceiling paneling) (Maloney 1977). Particleboard is $57 \%$ of total consumption of wood-based panels consumed and it is continuously growing at $2-5 \%$ annually. Particleboard consumption significantly increases each year. According to a report from Food and Agricultural Organization (FAO) of the United Nations, during 1998 world consumption of particleboard was $56,2 \times 10^{6} \mathrm{~m}^{3}$ and in 2012 it had risen to approximately $98 \times 10^{6} \mathrm{~m}^{3}$ (FAO 2012).

Considering the fact that the raw materials especially in natural resources sector are limited, the woodworking industry has made several efforts to ensure the sustainability of raw materials. Therefore, for providing wooden raw materials, special attention should be paid to wood wastes/residues from woodworking industries and agricultural residues, because the particleboard industry is able to use and consume a wide range of wooden and nonwooden lignocellulosic wastes/residues (Troger et al. 1998, Nemli et al. 2003, Bektas et al. 2005, Guntekin and Karakus 2008). Alternative raw materials such as agricultural residues and fast-growing species can play an important role in the particleboard industry in the future (Papadopoulos et al. 2004, Nemli et al. 2009). One of the natural resources that can be abundantly available in Iran is

\footnotetext{
${ }^{1,2}$ Assistant professor, Department of Paper and Packaging Technology, Faculty of Chemistry and Petrochemical Engineering,

Standard Research Institute (SRI), Karaj, Iran.

${ }^{3}$ Assistant professor, Department of Green Space Engineering, Malayer Branch, Islamic Azad University, Malayer, Iran

^ Corresponding author: b.kord@standard.ac.ir

Received: 20.04.2014 Accepted: 23.10.2014
} 
reed. Reeds cover vast regions in northern and southern Iran. There is a possibility of executing a harvest in Hoor-Alazim and Anzali lagoon as a natural site or habitat. According to a study in Hoor-Alazim, 80 tons per hectare of dried reed could be harvested. The use of reed fiber in particleboard production can help reduce the demand for wood fibers and also the environmental impact associated with wood fiber harvesting.

Much research has been done on the use of various nonwood fibers for particleboard manufacturing. Kalaycioglu and Nemli (2006) found that kenaf has potential as a raw material for particleboard manufacturing. They reported that the press temperature, press time, and shelling ratio positively affected the physical and mechanical properties of the panels. Azizi et al. (2011), were investigated the performance characterizations of particleboards made with wheat straw and waste veneer splinters. They found that with the exception of modulus of elasticity, all the mechanical and physical properties decreased with the increase of wheat straw content. Also, all the mechanical and physical properties of the boards were improved when the press temperature was increased from 140 to $170^{\circ} \mathrm{C}$. They reported that wheat straw and beech veneer splinters have potential as supplement fibrous materials, in combination with wood particles for particleboard manufacturing and indoor applications. Khanjanzadeh et al. (2012), were studied the utilization of bio-waste cotton stalks and underutilized paulownia in wood-based composite particleboard. The results indicated that the addition of cotton stalks and paulownia wood in particleboard improved mechanical properties of boards significantly. However, the water resistance decreased with increasing cotton stalk and paulownia wood particle contents.

The objective of this study was to use of the reed stem as a raw material for laboratory made threelayer particleboard and to test the physical and mechanical properties of panels to determine if they have required levels of properties for general uses. In addition, influence of press temperature and pressing cycle time on the physical and mechanical properties of particleboards made with reed stem and industrial wood particles was investigated.

\section{EXPERIMENTAL}

\section{Materials}

The raw material of this study included reed stem and industrial wood particles (consisting of mixed hardwood species such as alder, eucalyptus, poplar, beech and maple). Reed (Phragmites communis Trinius) stem was directly obtained from the Mahmodabad area, which is located in northern Iran; and industrial wood particles were supplied by Takhte Feshorde Shomal Co, Iran. Urea-formaldehyde (UF) adhesive with a solid content of $53 \%$, density of $1210 \mathrm{~kg} / \mathrm{m}^{3}$, viscosity of $15 \mathrm{cp}$, gelation time of $55 \mathrm{~s}$, and $\mathrm{pH}$ of 7,5 was purchased from Tehran Chasbsaz Co, Iran. Ammonium chloride $\left(\mathrm{NH}_{4} \mathrm{Cl}\right)$ solution (solid content: $20 \%$ ) was used as a hardener.

\section{METHODS}

Before production of boards, the reeds were chipped using industrial-scale drum-chipper; before the chips were reduced into smaller particles by a knife-ring flaker. The average size of reed particles was 8,65 $\mathrm{mm}$ in length, $1,82 \mathrm{~mm}$ in width and $0,37 \mathrm{~mm}$ in thickness and wood particles averaged $12,49 \times 2,73 \times 0,65$ $\mathrm{mm}^{3}$. Then the particles were oven-dried at $80{ }^{\circ} \mathrm{C}$ for $24 \mathrm{~h}$ to a moisture content of less than $3 \%$ prior to processing. 
The ratio of the mixture of reed and industrial wood particles were chosen at five levels of 0:100, 25:75, 50:50, 75:25 and 100:0 to manufacture the boards. Press temperature and pressing cycle time were selected at three levels of $170,180,190{ }^{\circ} \mathrm{C}$ and $5,6,7 \mathrm{~min}$, respectively. Other parameters such as resin content ( $8 \%$ and $10 \%$ UF resin were applied for the core and face layers, respectively), hardener content (2\%), press closing rate $(4,5 \mathrm{~mm} / \mathrm{min})$, press pressure $\left(30 \mathrm{~kg} / \mathrm{cm}^{2}\right)$, board thickness $(15 \mathrm{~mm})$, and target density $\left(700 \mathrm{Kg} / \mathrm{m}^{3}\right)$ were held constant. For each treatment, three replications were done. Based on these variables 45 board formulations were manufactured with three boards of each type resulting in 135 boards in total.

Before blending, reed and industrial wood particles were screened by a screening machine and the particles between 3 and 1,5 and 1,5 and $0,8 \mathrm{~mm}$ sieve were utilized in the core and outer layers, respectively. Then, the particles were introduced in a rotating drum-type blender and sprayed with UF and $\mathrm{NH}_{4} \mathrm{Cl}$ for 5 min to obtain a homogenized mixture. The materials were placed in a molding frame and spread to fill evenly. The resinated particles were then pressed into panel mat using a laboratory scale hydraulic hot press. The nominal dimensions of the boards were $320 \times 300 \times 15 \mathrm{~mm}^{3}$. Stop bars were used in the press to allow the same board thickness to be achieved for all the test runs. No wax or any other hydrophobic substance was applied for manufacturing of the boards. After pressing, all boards were trimmed to a final size of $250 \times 250 \times 15 \mathrm{~mm}^{3}$. Consequently, the board samples were conditioned for 2 weeks at $65 \%$ relative humidity and $25^{\circ} \mathrm{C}$. Finally, the modulus of rupture (MOR), modulus of elasticity (MOE), internal bonding strength (IB), water absorption (WA), and thickness swelling (TS) after 24 hour water soaking of samples was measured according to European standards (EN 310, EN 317, EN 319). The statistical analysis was conducted using SPSS programming (Version 13) method in conjunction with the analysis of variance (ANOVA) techniques. Duncan multiply range test (DMRT) was used to test the statistical significance at $\alpha=0,05$ level.

\section{RESULTS AND DISCUSSION}

In general, statistical analyses showed that the mechanical properties in terms of MOR, MOE and IB of the experimental boards were significantly influenced by the mixing ratio of fibrous materials; press temperature and press pressing cycle time (Table 1). The results of an ANOVA indicated that the individual and interaction effects of variables on the mechanical properties of panels are significantly. The average values of mechanical properties (MOR, MOE and IB) of panels are shown in table 2.

Table 1. Statistical analysis of mechanical properties of particleboards produced with different variables.

\begin{tabular}{|c|c|c|c|c|c|c|c|c|c|c|}
\hline \multirow{2}{*}{ Source of variations } & \multirow{2}{*}{ df } & \multicolumn{3}{|c|}{ MOR (MPa) } & \multicolumn{3}{|c|}{ MOE (MPa) } & \multicolumn{3}{|c|}{ IB (MPa) } \\
\hline & & SS & MS & $\mathbf{F}$ & SS & MS & $\mathbf{F}$ & SS & MS & $\mathbf{F}$ \\
\hline Fibrous mixture (A) & 4 & 0,751 & 0,188 & $0,220 *$ & 686205,113 & 171551,278 & $7,209 *$ & 1,990 & 0,497 & $58,094 *$ \\
\hline Press Temperature (B) & 2 & 13,587 & 6,793 & $7,949 *$ & 265060,396 & 132530,198 & $5,570^{*}$ & 0,420 & 0,210 & $24,534 *$ \\
\hline Press Time $(C)$ & 2 & 119,550 & 59,775 & $69,944 *$ & 2793003,945 & 1396501,973 & $58,688 *$ & 0,651 & 0,325 & $37,992 *$ \\
\hline$A \times B$ & 8 & 212,358 & 26,545 & $31,060 * *$ & 5313774,137 & 664221,767 & $27,914 *$ & 4,291 & 0,536 & $62,630 * *$ \\
\hline $\mathbf{A} \times \mathbf{C}$ & 8 & 1,071 & 0,134 & $0,157 *$ & 214477,314 & 26809,664 & $1,127 * *$ & 0,062 & 0,008 & $0,899^{* *}$ \\
\hline $\mathbf{B} \times \mathbf{C}$ & 4 & 1,632 & 0,408 & $0,477 * *$ & 42752,638 & 10688,159 & $0,449 * *$ & 0,050 & 0,012 & $1,456 * *$ \\
\hline $\mathbf{A} \times \mathbf{B} \times \mathbf{C}$ & 16 & 1,800 & 0,112 & $0,132 * *$ & 35206,595 & 2200,412 & $0,092 *$ & 0,133 & 0,008 & $0,971 * *$ \\
\hline Error & 90 & 76,915 & 0,855 & & 2141573,674 & 23795,263 & & 0,771 & 0,009 & \\
\hline Total & 135 & 41322,750 & & & $8,636 \mathrm{E} 8$ & & & 59,598 & & \\
\hline
\end{tabular}

Note: $\mathrm{df}=$ degree of freedom; $\mathrm{MS}=$ mean of squares; $\mathrm{SS}=$ sum of squares; $\mathrm{F}=\mathrm{F}$ value; $\mathrm{ns}=$ not significant.

*Significant difference at the $1 \%$ level $(\mathrm{p} \leq 0,01 \%)$

**Significant difference at the $5 \%$ level $(p \leq 0,05 \%)$ 
Table 2. Mechanical properties of experimental particleboard panels.

\begin{tabular}{|c|c|c|c|c|c|c|c|c|c|c|c|c|c|c|c|c|}
\hline \multirow{3}{*}{$\begin{array}{c}\text { Press } \\
\text { Temp } \\
\left({ }^{\circ} \mathrm{C}\right)\end{array}$} & \multirow{3}{*}{$\begin{array}{l}\text { Press } \\
\text { Time } \\
(\mathrm{min})\end{array}$} & \multicolumn{15}{|c|}{ Mixture of reed: industrial wood particles (\%) } \\
\hline & & \multicolumn{3}{|c|}{ 0:100 } & \multicolumn{3}{|c|}{$25: 75$} & \multicolumn{3}{|c|}{$50: 50$} & \multicolumn{3}{|c|}{$75: 25$} & \multicolumn{3}{|c|}{ 100:0 } \\
\hline & & $\begin{array}{l}\text { MOR } \\
\text { (MPa) }\end{array}$ & $\begin{array}{l}\text { MOE } \\
(\mathrm{MPa})\end{array}$ & $\begin{array}{c}\mathrm{IB} \\
(\mathrm{MPa})\end{array}$ & $\begin{array}{l}\text { MOR } \\
\text { (MPa) }\end{array}$ & $\begin{array}{l}\text { MOE } \\
\text { (MPa) }\end{array}$ & $\begin{array}{c}\mathrm{IB} \\
(\mathrm{MPa})\end{array}$ & $\begin{array}{l}\text { MOR } \\
\text { (MPa) }\end{array}$ & $\begin{array}{l}\text { MOE } \\
\text { (MPa) }\end{array}$ & $\begin{array}{c}\mathrm{IB} \\
(\mathrm{MPa})\end{array}$ & $\begin{array}{l}\text { MOR } \\
\text { (MPa) }\end{array}$ & $\begin{array}{l}\text { MOE } \\
\text { (MPa) }\end{array}$ & $\begin{array}{c}\mathrm{IB} \\
(\mathrm{MPa})\end{array}$ & $\begin{array}{l}\text { MOR } \\
\text { (MPa) }\end{array}$ & $\begin{array}{l}\text { MOE } \\
(\mathrm{MPa})\end{array}$ & $\begin{array}{c}\mathrm{IB} \\
(\mathrm{MPa})\end{array}$ \\
\hline \multirow{4}{*}{170} & 5 & 12,73 & 1728,67 & 0,42 & 13,86 & 1852,13 & 0,48 & 15,03 & 1975,48 & 0,55 & 16,19 & 2088,23 & 0,59 & 17,41 & 2116,77 & 0,63 \\
\hline & 6 & 13,82 & 1845,48 & 0,50 & 14,70 & 1968,03 & 0,54 & 16,22 & 2045,52 & 0,60 & 17,17 & 2159,11 & 0,64 & 18,19 & 2240,19 & 0,68 \\
\hline & 7 & 14,51 & 1933,33 & 0,58 & 15,38 & 2047,71 & 0,62 & 17,09 & 2133,88 & 0,66 & 18,36 & 2231,79 & 0,67 & 19,05 & 2308,65 & 0,72 \\
\hline & 5 & 13,57 & 1863,67 & 0,46 & 14,34 & 1982,19 & 0,53 & 16,27 & 2023,14 & 0,59 & 17,80 & 2119,30 & 0,62 & 18,15 & 2215,29 & 0,66 \\
\hline \multirow[t]{3}{*}{180} & 6 & 14,64 & 1970,59 & 0,53 & 15,72 & 2015,96 & 0,59 & 17,10 & 2137,25 & 0,65 & 18,29 & 2201,06 & 0,68 & 19,32 & 2352,17 & 0,71 \\
\hline & 7 & 15,33 & 2035,81 & 0,61 & 16,74 & 2180,18 & 0,65 & 18,27 & 2214,67 & 0,71 & 19,23 & 2292,85 & 0,73 & 20,41 & 2419,33 & 0,77 \\
\hline & 5 & 14,65 & 1931,63 & 0,52 & 15,55 & 2065,12 & 0,56 & 17,35 & 2145,37 & 0,63 & 18,19 & 2279,03 & 0,66 & 19,27 & 2324,18 & 0,70 \\
\hline \multirow[t]{2}{*}{190} & 6 & 15,57 & 2054,94 & 0,60 & 16,77 & 2144,57 & 0,63 & 18,11 & 2267,75 & 0,68 & 19,77 & 2363,16 & 0,70 & 20,51 & 2401,62 & 0,75 \\
\hline & 7 & 16,28 & 21687,77 & 0,66 & 17,42 & 2274,63 & 0,69 & 19,09 & 2320,66 & 0,74 & 20,40 & 2400,94 & 0,75 & 21,38 & 2474,45 & 0,83 \\
\hline
\end{tabular}

Based on EN standards 11,5 MPa, $13 \mathrm{MPa}$ and $1600 \mathrm{MPa}$ are the minimum requirements for modulus of rupture, and modulus of elasticity of particleboard panels for general uses and furniture manufacturing, respectively (EN 312-2, EN 312-3). The average modulus of rupture and modulus of elasticity ranged from 12,73 to $21,38 \mathrm{MPa}$ and 1728 to $2474 \mathrm{MPa}$, respectively (Table 2). According to the test results, all of the particleboards produced were higher than the EN requirements. It can be seen that the treatment with $100 \%$ reed, $190{ }^{\circ} \mathrm{C}$ press temperature and 7 min press time has highest MOR and MOE values among the other types of specimens.

The range of data in internal bonding was from 0,42 to $0,83 \mathrm{MPa}$ (Table 2). The internal bonding requirements are $0,24 \mathrm{MPa}$ for general purpose boards; $0,35 \mathrm{MPa}$ for interior fitments, load-bearing boards and 0,50 MPa for heavy duty load bearing boards by EN standards (EN 312-2, EN 312-3, EN 312-4, EN 312-6), respectively. According to the test results, all of the particleboards produced were higher than the requirement for general purpose, interior fitments, load-bearing boards and heavy duty load bearing boards. It can be seen that the treatment with $100 \%$ reed, $190{ }^{\circ} \mathrm{C}$ press temperature and $7 \mathrm{~min}$ press time has highest IB values among the other types of specimens.

The results showed that mechanical properties (MOR, MOE and IB) increased as the amount of reed particles increased. The reason for this improvement can be related to the low density of reed particles which causes more densification. This in turn leads to better adhesion during hot pressing. The positive influence of press temperature and press time can also be seen in terms of improved mechanical properties. It is related closely with resin curing, decreasing of particle wettability, and increasing of particle surface area (Nemli 2002, Ashoria and Nourbakhsh 2008). There are two conceptual approaches to explain those phenomenons. First, temperature will affect of UF bonding by facilities the liquid access and acceleration diffusion of resin molecule in particles. At low temperature, resin diffusion in particles will become lower that it caused the decrease in mechanical interlocking. Second, pressing temperature affected the chemical substrats changes such as lignin melting, modification of hydrogen bonding that will increase the bonding strength value (Ashoria and Nourbakhsh 2008, Hashim et al. 2011, Iswanto et al. 2014).

The statistical results are shown in tables 3 and 4 and demonstrate the influence of mixing ratio of fibrous materials, press temperature and press pressing cycle time on the WA and TS properties of produced boards. The results of an ANOVA indicated that the individual and interaction effects of variables on the physical properties of panels are significantly. 
Table 3. Statistical analysis of physical properties of particleboards produced with different variables.

\begin{tabular}{|c|c|c|c|c|c|c|c|}
\hline \multirow{2}{*}{ Source of variations } & \multirow{2}{*}{ df } & \multicolumn{3}{|c|}{ WA (\%) } & \multicolumn{3}{|c|}{ TS (\%) } \\
\hline & & SS & MS & $\mathbf{F}$ & SS & MS & $\mathbf{F}$ \\
\hline Fibrous mixture (A) & 4 & 2097,933 & 524,483 & $84,733^{*}$ & 1046,784 & 261,696 & $125,028^{*}$ \\
\hline Press Temperature (B) & 2 & 1375,415 & 687,708 & $111,102 *$ & 262,083 & 131,042 & $62,607 *$ \\
\hline Press Time (C) & 2 & 3963,790 & 1981,895 & $320,184 *$ & 2438,431 & 1219,215 & $582,493^{*}$ \\
\hline $\mathbf{A} \times \mathbf{B}$ & 8 & 6594,507 & 824,313 & $133,171 *$ & 2429,268 & 303,658 & $145,076^{*}$ \\
\hline $\mathbf{A} \times \mathbf{C}$ & 8 & 66,484 & 8,310 & $1,343^{* *}$ & 79,135 & 9,892 & $4,726^{* *}$ \\
\hline $\mathbf{B} \times \mathbf{C}$ & 4 & 46,187 & 11,547 & $1,865 * *$ & 25,453 & 6,363 & $3,040^{* *}$ \\
\hline $\mathbf{A} \times \mathbf{B} \times \mathbf{C}$ & 16 & 168,179 & 10,511 & $1,698^{* *}$ & 94,537 & 5,909 & $2,823^{* *}$ \\
\hline Error & 90 & 557,088 & 6,190 & & 188,379 & 2,093 & \\
\hline Total & 135 & 141288,586 & & & 41007,912 & & \\
\hline
\end{tabular}

Note: $\mathrm{df}=$ degree of freedom; $\mathrm{MS}=$ mean of squares; $\mathrm{SS}=$ sum of squares; $\mathrm{F}=\mathrm{F}$ value; $\mathrm{ns}=$ not significant.

*Significant difference at the $1 \%$ level $(\mathrm{p} \leq 0,01 \%)$

**Significant difference at the $5 \%$ level $(\mathrm{p} \leq 0,05 \%)$

Results indicate that as the amount of reed particles increases, the water absorption of the boards increases significantly. Average water absorption of the samples ranged from 30,13\% to 64,93\% for $24 \mathrm{~h}$ immersion (Table 4). Reed particles affected the WA negatively. This is due to high amount of pith which consists of parenchyma cells. The parenchyma tissue makes the panels more water uptake due to the presence of more hydroxyl group which enables more hydrogen bonding formation. In addition, the parenchyma behaved like a sponge making it easier for the panels to absorb water. Similar results were reported in previous studies (Ntalos and Grigoriou 2002, Kalaycioglu and Nemli 2006, Dahmardeh Ghalehno et al. 2011).

The thickness swelling values of boards made with different amounts of fibrous mixture, at different levels of press temperature and press pressing cycle time are shown in Tables 3 and 4 . Based on EN Standards, particleboard should have a maximum thickness swelling value of $8 \%$ for $24 \mathrm{~h}$ immersion. The mean TS data of the particleboards obtained vary from $9,22 \%$ to $37,89 \%$ for $24 \mathrm{~h}$ immersion (Table 4). The results indicate that as the reed content increased, the thickness swelling of the boards increased significantly. It is obvious that reed particles cause higher board swelling, which is the result of the lower adhesive content per surface area of reed particles in comparison to wood particles. This is due to the fact that reed particles are wider and considerably thinner, and consequently have a much larger surface area per weight unit than wood particles. Similar results were reported in previous studies (Bektas et al. 2005, Nemli et al. 2009, Azizi et al. 2011).

Table 4. Physical properties of experimental particleboard panels.

\begin{tabular}{|c|c|c|c|c|c|c|c|c|c|c|c|}
\hline \multirow{3}{*}{$\begin{array}{c}\text { Press } \\
\text { Temp } \\
\left({ }^{\circ} \mathrm{C}\right)\end{array}$} & \multirow{3}{*}{$\begin{array}{l}\text { Press } \\
\text { Time } \\
(\mathrm{min})\end{array}$} & \multicolumn{10}{|c|}{ Mixture of reed: industrial wood particles (\%) } \\
\hline & & \multicolumn{2}{|c|}{ 0:100 } & \multicolumn{2}{|c|}{$25: 75$} & \multicolumn{2}{|c|}{$\mathbf{5 0 : 5 0}$} & \multicolumn{2}{|c|}{$75: 25$} & \multicolumn{2}{|c|}{ 100:0 } \\
\hline & & $\begin{array}{l}\text { WA } \\
\text { (\%) }\end{array}$ & $\begin{array}{l}\text { TS } \\
(\%)\end{array}$ & $\begin{array}{l}\text { WA } \\
(\%)\end{array}$ & $\begin{array}{l}\text { TS } \\
(\%)\end{array}$ & $\begin{array}{l}\text { WA } \\
\text { (\%) }\end{array}$ & $\begin{array}{l}\text { TS } \\
\text { (\%) }\end{array}$ & $\begin{array}{l}\text { WA } \\
\text { (\%) }\end{array}$ & $\begin{array}{l}\text { TS } \\
(\%)\end{array}$ & $\begin{array}{l}\text { WA } \\
(\%)\end{array}$ & $\begin{array}{l}\text { TS } \\
(\%)\end{array}$ \\
\hline \multirow{3}{*}{170} & 5 & 39,66 & 17,89 & 42,47 & 22,28 & 50,83 & 28,44 & 58,33 & 33,68 & 64,93 & 37,89 \\
\hline & 6 & 36,31 & 14,05 & 39,35 & 18,34 & 46,07 & 24,58 & 54,15 & 29,02 & 61,67 & 33,05 \\
\hline & 7 & 33,93 & 12,61 & 36,41 & 15,31 & 42,46 & 21,61 & 51,46 & 26,08 & 58,09 & 30,61 \\
\hline \multirow{3}{*}{180} & 5 & 37,69 & 15,66 & 39,27 & 19,84 & 45,26 & 25,13 & 53,07 & 30,55 & 60,19 & 34,66 \\
\hline & 6 & 34,09 & 12,46 & 36,67 & 16,23 & 42,90 & 22,02 & 49,11 & 27,74 & 57,21 & 31,46 \\
\hline & 7 & 31,19 & 10,49 & 32,71 & 13,69 & 38,77 & 20,27 & 45,23 & 25,01 & 53,61 & 28,49 \\
\hline \multirow{3}{*}{190} & 5 & 35,21 & 13,93 & 37,14 & 17,32 & 41,39 & 21,67 & 50,67 & 26,43 & 55,13 & 30,93 \\
\hline & 6 & 32,61 & 10,10 & 34,67 & 14,67 & 39,25 & 18,23 & 46,72 & 23,11 & 52,83 & 27,10 \\
\hline & 7 & 30,13 & 9,22 & 32,85 & 11,98 & 37,24 & 16,06 & 42,67 & 20,36 & 49,72 & 24,22 \\
\hline
\end{tabular}


Also, it should be noted that the WA and TS of the boards were affected by press temperature and press pressing cycle time (Table 3). The WA and TS of the experimental particleboards increased significantly with a decrease in press temperature and press time. The decrease of the WA and TS thickness swelling in the studied composites can be attributed to the same reasons as discussed concerning mechanical properties. It can be seen that the treatment with $100 \%$ reed, $170{ }^{\circ} \mathrm{C}$ press temperature and $5 \mathrm{~min}$ press time has highest WA and TS values among the other types of specimens.

\section{CONCLUSIONS}

The following conclusions could be drawn from the results of the present study:

The reed particles usage increases the MOR, MOE, IB, WA and TS of particleboard.

The press temperature and press time positively affected the physical and mechanical properties of the panels.

Based on the initial mechanical property results of this study, it can be stated that reed stem has potential as a raw material for particleboard manufacturing.

Additional work is needed to determine the effects of the reed particles usage on the formaldehyde emission and surface roughness of particleboard, as well as improving the thickness swell performance. 


\section{REFERENCES}

Azizi, K.; Tabarsa, T.; Ashori, A. 2011. Performance characterizations of particleboards made with wheat straw and waste veneer splinters. Compos Part B 42: 2085-2089.

Alma, M.H.; Kalaycioglu, H.; Bektas, I.; Tutuo, A. 2005. Properties of cotton carpel-based particleboards. Ind Crops Prod 22: 141-149.

Ashoria, A.; Nourbakhsh, A. 2008. Effect of press cycle time and resin content on physical and mechanical properties of particleboard panels made from the underutilized low-quality raw materials. Ind Crops Prod 28: 225-230.

Bektas, I.; Guler, C.; Kalaycioglu, H.; Mengenoglu, F.; Nacar, M. 2005. The manufacture of particleboards using sunflower stalks (Helianthusannuus I.) and poplar wood (Populus alba L.). J Compos Mater 39: 467-473.

Dahmardeh-Ghalehno, M.; Madhoushi, M.; Tabarsa, T.; Nazerian, M. 2011. The manufacture of particleboards using mixture of reed (surface layer) and commercial species (middle layer). Eur $J$ Wood Prod 69(3): 341-344.

European Committee for Standardization. 1993. Wood-based panels, determination of modulus of elasticity in bending and bending strength. EN 310. 1993, Brussels, Belgium.

European Committee for Standardization. 1996. Particleboards-specifications-Part 2: requirements for general-purpose boards for use in dry conditions. EN 312-2. 1996, Brussels, Belgium.

European Committee for Standardization. 1996. Particleboards-specifications-Part 2: requirements for boards for interior fitments (including furniture) for use in dry conditions. EN 312-3. 1996, Brussels, Belgium.

European Committee for Standardization. 1993. Particleboards and fiberboards, determination of swelling in thickness after immersion. EN 317. 1993, Brussels, Belgium.

European Committee for Standardization. 1993. Particleboards and fiberboards, determination of tensile strength perpendicular to plane of the board. EN 319. 1993, Brussels, Belgium.

FAO. 2012. Forest product statistics, Global forest products facts and figures.

Guntekin E.; Karakus, B. 2008. Feasibility of using eggplant (Solanum melongena) stalks in the production of experimental particleboard. Ind Crops Prod 27: 354-358.

Iswanto, A.H.; Azhar, I.; Supriyanto, M.; Susilowati, A.; 2014. Effect of resin type, pressing temperature and time on particleboard properties made from sorghum bagasse. Agric For Fishe 3(2): 62-66.

Kalaycioglu, H.; Nemli, G. 2006. Producing composite particleboard from kenaf (Hibiscus cannabinus L.) stalks. Ind Crops Prod 24(2): 177-180.

Khanjanzadeh, H.; Bahmani, A.; Rafighi, A.; Tabarsa, T. 2012. Utilization of bio-waste cotton (Gossypium hirsutum L.) stalks and underutilized paulownia (Paulownia fortunie) in wood-based composite particleboard. Afric J Biotech 11(31): 8045-8050. 
Maloney, T.M. 1977. Modern Particleboard and Dry Process Fiberboard Manufacturing. Miller Freeman Publications, Inc., San Francisco.

Nemli, G. 2002. Factors affecting the production of E1 type particleboard. Turk J Agric For 26: 31-36.

Nemli, G.; Kirci, H.; Serdar, B.; Ay, N. 2003. Suitability of kiwi (Actinidia sinensis Planch.) pruning for particleboards manufacturing. Ind Crops Prod 17 (1): 39-46.

Nemli, G.; Demirel, S.; Gümüokaya, E.; Aslan, M.; Acar, C. 2009. Feasibility of incorporating waste grass clippings (Lolium perenne L.) in particleboard composites. Waste Manage 29: 1129-1131.

Ntalos, G.A.; Grigoriou, A.H. 2002. Characterization and utilization of wine pruning as a wood substitute for particleboard production. Ind Crops Prod 16: 59-68.

Papadopoulos, A.N.; Hill, C.A.S.; Gkaraveli, A.; Ntalos, G.A.; Karastergiou, S.P. 2004. Bamboo chips (Bambusa vulgaris) as an alternative lignocellulosic raw material for particleboard manufacture. Holz Roh-Werkst 62: 36-39.

Rokiah-Hashim, R.; Said, N.; Lamaming, J.; Baskaran, M.; Sulaiman, O.; Sato, M.; Hiziroglu, S.; Sugimoto, T. 2011. Influence of press temperature on the properties of binderless particleboard made from oil palm trunk. Mater Des 32: 2520-2525.

Troger, F.; Wegener, G.; Seeemann, C. 1998. Mischantus and flax as raw material for reinforced particleboards. Ind Crops Prod 8 (2): 113-121. 